\title{
COMMENTS
}

\section{THE CONDOMINIUM CONVERSION PROBLEM: CAUSES AND SOLUTIONS}

In many major urban and suburban areas, condommiums ${ }^{1}$ and cooperatives $^{2}$ are becoming a significant element of the housing market. ${ }^{3}$

THE FOLLOWING CITATIONS WILL BE USED IN THIS COMMENT:

Rental Accommodations Act of 1975: Hearings on H. Cong. Res. 399 Before the Subcomm. on Commerce, Housing, \& Transportation of the House Comm. on the District of Columbia, 94th Cong., 1st Sess. (1976) [hereinafter cited as Rental Accommodations Hearings];

F. Hayek, M. Friedman, G. Stigler, B. De Jouvenel, F. Paish, F. Pennance, E. Olsen, S. Rydenfelt, \& M. WALKer, Rent Control: A Popular Paradox (1975) [hereinafter cited as RENT CONTROL];

Anderson \& Cody, Tax Considerations of the Condominium Sponsor and Purchaser, 48 ST. JoHN'S L. REv. 887 (1974) [hereinafter cited as Anderson \& Cody];

Rohan, "The Model Condominium Code"-A Blueprint for Modernizing Condominium Legislation, 78 CoLUM. L. Rev. 587 (1978) [hereinafter cited as Rohan]; as Utt].

Utt, Rent Control: History's Unlearned Lesson, 7 REAL Est. REv. 87 (1978) [hereinafter cited

1. A condominium has been described as follows:

In a condominium, an individual has fee title to his own unit and, with the owners of other umits, has an undivided interest in the common elements and facilities that serve the development.

The common elements typically include such things as land, roofs, floors, main walls, stairways, Iobbies, halls, parking space, and comununity and commercial facilities. These coinunon elements and facilities are usually mamtained by an association of owners (which in some jurisdictions is referred to as a Council of Co-owners or similar name). Each unit owner makes a monthly contribution to the association covering his share of the costs of maintaming and operating the common elements.

Taxes and special assessinents are levied against individual units, not against the whole project or building. Also, each unit bears its own mortgage. Thus, the owner is not liable for the mortgage or real estate taxes of the others. All states, and the District of Columbia, Puerto Rico, and the Virgin Islands, have enacted some form of legislation recognizing condominium ownerslip.

[Reference File 2] Hous. \& DEv. Rep. (BNA) 25:0011 (1978).

2. A cooperative may be described as follows:

A cooperative is a member-owned corporation. A member of a cooperative does not directly own his dwelling umit, as in a condomimium. Rather, the member has a membership certiflcate or stock in a corporation which owns the property. Meunbership in the cooperative carries with it the exclusive right to occupy a dwelling unit in the development and to participate in the operation of the cooperative corporation either as a member of the Board of Directors or as a voter in the same manner as a shareholder in Id. any other corporation.

3. For the purposes of this Comment the distinctions between condominiums and cooperatives are not important. The term "condommium" will be used to refer to both types of housing unless otherwise specified. 
A primary feature of the condominium boom, accounting for the largest share of new condominium units on the market, is the conversion of rental apartments to condominiums. One survey estimates ${ }^{4}$ that conversions have doubled from approximately 50,000 units in 1977 to 100,000 units in 1978.5 Approximately seventy-five percent of these conversions took place im seven major markets: New York, Chicago, Houston, Seattle, Denver, Los Angeles, and Washington, D.C. ${ }^{6}$ When the data are compiled, it is likely that 130,000 units will have been converted in $1979 .^{7}$

The surge in condominium conversions is attributable to a number of factors. ${ }^{8}$ Demand for condominiums is strong, particularly for converted units, which are generally priced lower than newly constructed umits. At the same time, conversion provides an opportunity for landlords with ever decreasing profits to sell their properties for substantial gains. ${ }^{9}$

Condominium conversion has many benefits. Conversion meets the strong demand for condominium ownership and offers one of the best long-range solutions for urban decay. ${ }^{10}$ There are, however, niany negative effects associated with the process. Conversion displaces existimg tenants who do not want or cannot afford to buy units in the converted building. Each conversion also reduces available rental housing, making it difficult for displaced tenants to find suitable alternative housing. The burden of the conversion boom clearly falls niost heavily on the poor and the elderly, groups that can least afford to

4. It is impossible to determine the number of conversions with complete precision since no governinent agency keeps such annual statistics. The Census Bureau will begin compiling this data in 1980.

5. 6 Hous. \& DEv. REP. (BNA) 1094 (1979). The study was made by Advance Mortgage Corporation and Citicorp Real Estate, Inc.

6. Id. Among these markets, almost half of the conversions took place in New York City and Chicago. In New York City approximately 20,500 units were convertcd (nostly in cooperative form) and in Chicago 24,000 units were converted. Id.

7. Id. Representative Benjamin S. Rosenthal believes that the number of conversions could range as high as 250,000 umits. Washington Post, Sept. 8, 1979, § E, at 1, col. I.

8. See Rohan 587-88; Wood, Condos: Threat to a "City of Renters," Washington Post, May $26,1979, \S \mathrm{A}$, at 17 , col. 1. Although the conversion situation has received extensive pubhicity only recently, the problein can be traced back to the immediate post-World War II era. Cooperative conversion became a serious problem in the postwar era as landlords attempted to escape the constraints of rent control. See Woods v. Krizan, 176 F.2d 667 (8th Cir. 1949); Bratt, Cooperative Apartments: A Survey of Legal Treatment and an Argument for Homestead Protection, 1978 U. ILL. L.F. 759, 785-87; Marks \& Marks, Coercive Aspects of Housing Cooperatives, 42 ILL. L. REv. 728, 729 n.6 (1948) (describing the spread of cooperative conversions and the "exorbitant" prices being asked).

9. See notes $32-49$ infra and accoinpanying text.

10. Rohan 599. 
purchase the converted units. ${ }^{11}$

This Comment discusses the factors responsible for the increase in condominium demand and conversions as well as state and local regulatory responses to conversion. The first part analyzes the factors contributing to this strong consumer demand and explains the conversion incentives for landlords and developers that operate to assure a steady supply. The second part of this Comment discusses advantages and disadvantages of conversion from a public policy perspective. Finally, this Comment focuses on various legislative responses and recommends an approach for future regulation.

\section{Explanations of the Conversion Phenomenon}

\section{A. Demand for Condominium Ownership}

Several factors explain the increasing demand for new and converted condominiums. First, the coming of age of the "baby boom generation" has brought an imcrease in the number of persons in the housebuying age bracket, ${ }^{12}$ an effect expected to contimue at least until the mid-1980s. ${ }^{13}$

A second factor is the increase in smaller households searching for units designed to accommodate their size. Later marriages and the postponement of having children account for a significant increase in one- and two-person households. ${ }^{14}$ In addition, smgle females are becommg significant wage earners and home buyers, contributing further to this increase.

Third, for young professionals making increasimgly higher salaries, homeownership in the form of a condominium offers many tax advantages over rental living. When a buyer invests in a condominium he purchases real property, ${ }^{15}$ entitling him to the same deductions allowed any owner of conventional residential property. ${ }^{16}$ The condomimium

11. See notes 81-86 infra and accompanying text. See Cafritz, The Benefits of Going Condo, Washington Post, May 19, 1979, \& A, at 15, col. 1 .

12. Professor Sternlieb of Rutgers University feels that the baby boom generation accounted for a sharply expanded rental market between the mid-1960s and mid-1970s, but that demand for rental units will decline almost $12 \%$ by the early 1980 s. He states that the "baby booun generation" is entering its thirties, the prime house-buymg years. Ramirez, Apartments Are Scarce But the Outlook Dims for New Construction, Wall St. J., Jan. 24, 1979, at 1, 36, col. 3.

13. Id.

14. One authority estimates that approximately $60-70 \%$ of those in today's condouninium market are married and have no children. The approximate size of the average condouninium household is 2.5 persons. Schwab, Factors to be Considered, in Condominium AND CoOpERATIve CONVERSIONS 13 (1979).

15. See note 1 supra.

16. The same advantages would, of course, be gained upon purchase of traditional single- 
owner may deduct state and local real property taxes assessed against the unit, ${ }^{17}$ as well as interest paid on mortgage liabilities. ${ }^{18}$ Along with these benefits, the condominium owner may also deduct any amounts lost on the condominium unit due to "fire, storm . . . or other casualty" that are uncompensated by imsurance. ${ }^{19}$ In contrast, renters cannot take advantage of any of these benefits, for no purchase of real property is mvolved. Furthermore, additional tax benefits may be realized on a subsequent sale of the property. The Internal Revenue Code allows the condominium owner to deduct from gross income sixty percent of any gam realized on the subsequent sale of the condominium unit. ${ }^{20}$ The owner thus pays taxes on only forty percent of the realized gain. The seller obtams a further advantage if the gain realized on the sale is used for acquisition of a new residence: if the condominium sold was the taxpayer's principal residence and he apphes the gain from the sale to the purchase of a new principal residence within eighteen months, the taxpayer may defer the tax hability until the subsequent sale of the acquired unit. ${ }^{21}$ This provision gives the taxpayer an opportunity to make a profit on money effectively borrowed from the federal treasury without interest.

Probably the two greatest advantages of condominium ownership over rental arrangements are the acquisition of equity and the appreciation in property value. As the condominium owner makes each mortgage payment, he acquires equity 22 in the property that nuay be recaptured in a subsequent sale of the condominium unit. Renters do not enjoy this advantage, simce rental payments can never be recovered. ${ }^{23}$ Condominiums are also desirable because their value appreci-

family dwellings. Many buyers may, however, find the cost of such property prohibitively high. Condominiums provide the same tax advantages without the high capital costs.

17. I.R.C. \& 164(a)(1). See generally Anderson \& Cody 899-900. Property taxes assessed against the commonly owned areas and the underlyimg property may also be deducted. Id.

18. I.R.C. \& 163(a) (which allows a deduction for "all interest paid or accrued within the taxable year on indebtedness").

19. Id. $\S 165(\mathrm{a})$-(c). Section $165(\mathrm{~b})(3)$ requires that the property be "not connected with a trade or busimess" for the owner to be entitled to this tax deduction.

20. Id. $\$ \S 1220(a), 1221$. This advantage is particularly important to condominium sellers because of the extremely high appreciation rates of converted condominiums. See notes 22-25 infra and accompanying text.

21. 1.R.C. $\S 1034$ (a). The taxpayer will be taxed during the purchase year on the amount of gain that exceeds the purchase price of the new residence. Id. See Anderson \& Cody 900.

22. Equity is defined as "[t]he remaining interest belouging to one who has pledged or mortgaged his property, or the surplus of value which may remain after the property has been disposed of for the satisfaction of hens." BLACK's LAW DICTIONARY 484 (5th ed. 1979).

23. The desirability of equity acquisition explains the willingness of buyers to pay purchase prices that exceed their forner rental costs for comparable dwellings. See.Turpin, Condos and Ghosts, Los Angeles Tinnes, Apr. 22, 1979, § X, at 1, col. 1. 
ates rapidly. In most markets condominiums appreciate a mimimum of twenty percent in the first year after conversion; in some markets the units have appreciated as inuch as fifty percent in the first year. ${ }^{24}$ Thereafter, aside from units in downtown areas, the appreciation rate is roughly equivalent to that for single family hoines.25 Clearly, investment in converted units offers one of the best hedges agamst inflation.

Finally, as American lifestyles become increasingly oriented toward leisure, the demand for onsite amenities and recreational facilities grows. ${ }^{26}$ Condominiums offer hoineowners the use of facilities such as swimming pools, tennis courts, and elevators at a significantly lower cost than would be possible in a single family dwelling. ${ }^{27}$ Since the condominiun owner is a tenant in common with regard to recreational facilities, he pays only his pro rata share of the cost and maintenance. Furthermore, since maintenance is overseen by a board of managers, who generally hire full-time einployees, the condoninium owner avoids all the inaintenance responsibilities that normally accompany ownership of these facilities while enjoying all the benefits.

While the factors discussed thus far explain the current demand for condominium units generally, there are additional factors that explain the even greater demand for converted condominiuin units. One factor accounting for this increased demand is the lower price of converted units compared to new units. ${ }^{28}$ As costs of materials, labor, financing, and marketing increase, the price of newly built condominiuin units cannot remain competitive with the price of converted units. ${ }^{29}$ In addition, when rental buildings are converted into condomimiunss, most renting tenants are given the chance to purchase their units at substantial discounts. ${ }^{30}$

24. $I d$.

25. Id. The author attributes this appreciation phenomenon to the pricing policies of the professional developer-converter, who prices the units below market price for quick sales and profits.

26. Rohan 587-88.

27. Id.

28. A Washington, D.C., newspaper reports that despite the number of high-cost condominiums, there are also many moderately priced units on the market, "[m]any of [which] are in newly converted apartmeut buildings." Harney, Condos 25\% of D.C. 1979 Sales, Washington Post, Aug. $4,1979, \S \mathrm{E}$, at 1,12 , col. 4.

29. See Condominium Consumer Protection Act of 1975: Hearings on S. 2273 Before the Senate Comm. on Banking, Housing \& Urban Affairs, 94th Cong., 1st Sess. 14 (1975) (statenent of Carla A. Hills); id. 290 (statement of Richard Arkin); McKelvy, Renters to Become Extinct, Investor Says, Chicago Tribune, June 24, 1979, § N14, at 1E, col. 2.

30. See, e.g., Wall St. J., June 4, 1979, at 1, 31, col. 3. All residents of a Fairfax, Virginia, conversion project were offered discounts of $\$ 3,000$ to $\$ 5,000$ on the purchase of their units originally priced at $\$ 27,500$ to $\$ 46,000$. Those who had hived $\mathrm{m}$ the coinplex for 30 years or more, and those elderly tenants who had lived in the complex for 10 years or more, were offered additional 
A further advantage of conversion over new condominium construction is that conversion allows the relatively inexpensive use of the choice central city locations of older buildings. Demand for housing in close proximity to business district employment is growing, especially with higher costs of commuting due to increased fuel prices. ${ }^{31} \mathrm{New}$ downtown construction either must be on expensive and increasingly rare vacant land or else include the cost of demolition in the already higher prices.

\section{B. Supply: Incentives for Landlords and Developers to Convert}

Strong demand for condominium units is only half of the explanation for the current conversion phenomenon. There are also strong economic and practical incentives inducing many landlords either to convert their buildings into condominiums themselves, or to sell to developers who will then convert. In a nutshell, landlords convert because profit margins for rental property are decreasing while substantial profits can be made by selling either individual units to homebuyers or entire buildings to developers.

For landlords, conversion is an effective alternative to dealing with the rapidly rising costs and slowly rismg rents that result in eroding profits. Between 1972 and 1977, the consumer price index rose more than forty-one percent. ${ }^{32}$ At the same time, building costs increased at an even faster rate of fifty percent. ${ }^{33}$ Rapidly rismg energy and utility prices increased the cost of maintaiming rental buildings even further. ${ }^{34}$ If rents kept up witl these mcreased costs, there would be no imcentive to convert. However, landlords in all but the highest rent districts have been unable to raise rents rapidly enough to keep pace with inflation. ${ }^{35}$

discounts. Thus, some couples were able to purchase their units for $\$ 34,500$, about $\$ 11,000$ less than the market price. Id. at 31, col. 4.

31. Donsky, Carter, Congress Weigh Federal Role in Urban Economic Development, 37 CoNG. Q. WEEKLY REP. 24, 26 (1979). A 1978 report estimates that approximately $30 \%$ of condomimium occupants come from the suburbs. Turpim, Condominiums Termed Best Tool for Recycling of Land, Los Angeles Times, Nov. 13, 1978, § 1, at 26, col. 1. That figure is now probably somewhat greater due to the significant rise in gasoline prices beginning in the summer of 1979 .

32. Ramirez, supra note 12 , at 36 , col. 3 .

33. Id.

34. Between 1970 and May of 1978 fuel and utility costs rose $99 \%$. Chicago Tribune, June 9 , $1979, \S \mathrm{Nl}$, at 8 , col. 1. This figure vastly understates the current situation in light of the high energy cost increases during the second half of 1979.

35. Between 1970 and May of 1978 , rents rose approximately $47 \%$ while building costs rose $88 \%$ and fuel and utility costs rose $99 \%$. Id; see McKelvy, Pros, Cons of Converting Apartment Buildings to Condo, Chicago Tribune, June 24, 1979, § N14, at 1E, col. 2; Ramirez, supra note 12, at 1, col. 3 (quoting Keuneth Rose, a Princeton University economics professor, who states: "Rents have risen only about half the general rate of infiation . . ."); Washburn, How, Why Cities Curb Condos, Chicago Tribune, Apr. 1, 1979, § N14, at 2, col. 2 (quoting James Banks, Executive 
The major impediment to meeting costs is rent control, or the fear of it. ${ }^{36}$ It is no comcidence that many cities facing the most serious conversion problems are rent control cities, ${ }^{37}$ and as the rent control movement spreads, ${ }^{38}$ condominium conversion problems are likely to follow.

The ever decreasing profitability of maintaining rental housing contrasts with the increased profitability of conversion, either by the landlord himself or by sale to a developer." "Individually inarketed umits provide a significantly higher return in comparison with the amount that could be realized on a single sale of the entire complex."40 One authority advises that condominiun conversion should yield a minimum profit on the total sales price of each individual unit of twenty percent. ${ }^{41}$ Profits may, in fact, be substantially higher.

In addition to the pure cost-return factors inducing landlords to convert or sell, tax laws also encourage conversion rather than inaintenance of buildings as rental properties. Many owners of older rental buildings sell because they have used up their depreciation allowances. ${ }^{42}$ Without depreciation deductions to offset income, rental apartment buildings lose any tax advantage they may have previously held for their owners. As imterest rates soar, refinancing of rental property becomes more and more difficult, thus precluding another tax advantage, the deduction of interest. ${ }^{43}$ Finally, the Tax Reform Act of $1976^{44}$ limited the tax shelter under which owners of rental buildings could deduct accelerated depreciation on used residential rental property against other income. ${ }^{45}$ Since the amount of accelerated deprecia-

Vice President of the Washington, D.C. Board of Realtors, who states: "One of the major reasons for condo conversions is the owners have found rental units uneconomical").

36. One prominent investor has stated: "A number of us would prefer to be in the rental business, . . . but the rental business is going out of style because of rent control." Camp, Condominium Eligibility Soaring, Washington Post, Mar. 2, 1979, § A, at 1, 8, col. 1. "Virtually every instance of rent control deinonstrates its negative effects. Private construction of rental units is discouraged, shortages occur, the profitability of apartment project declines, and maintenance is deferred as revenues diminish." Utt 90 . See notes 78-80 infra and accompanying text.

37. See, e.g., Brookline, Mass., By-laws, art. XXXVIII (as amended May 7, 1979); Cambridge, Mass., Ordinance 926 (July 19, 1979).

38. For a description of current organized efforts to institute rent control or to strengthen existing controls in California, New York, New Jersey, Maryland, Washington, and Connecticut, see 7 Hous. \& DEv. ReP. (BNA) 226-27 (1979).

39. "Apartment buildings across the country are worth more sold in parts as condommiums than whole as a rental building." McKelvy, supra note 35, at 1E, col. 2.

40. Comment, Tenant Protection in Condominium Conversions: The New York Experience, 48

ST. JohN's L. Rev. 978, 982 (I974).

41. Schwab, supra note 14 , at 19.

42. See I.R.C. $\$ 167$.

43. See note 18 supra.

44. Pub. L. No. 94-455, 90 Stat. 1520 (1976) (codified in scattered sections of 26 U.S.C.).

45. I.R.C. $\S 167(\mathrm{j})(5)$. 
tion an owner may deduct is decreased, maintaining a rental building is no longer a tax shelter. ${ }^{46}$ The tax laws also encourage sale by providing favorable capital gains treatment for high profits the owner may realize on the sale. ${ }^{47}$ As a result, landlords generally prefer to sell the whole building to condominium developers for the advantage of capital gains treatment.

Profits from sale to a developer will exceed profits froin sale to an investor wishing to maintain the property for rental purposes because the building is worth more to a developer due to the profitability of condominium developinent. Admittedly, a developer will not be entitled to capital gams treatment on profits realized from the sale of the units since the property is most certainly "held by the taxpayer primarily for sale . . . in the ordinary course of . . . business." 48 Nevertheless, by purchasing the building on borrowed money and a sinall personal equity investment, he can turn quick sales into substantial profits on a small investment. ${ }^{49}$

Developers wishing to capitalize on the high demand for condominiums see conversion as an attractive alternative to new construc-

46. McKelvy, supra note 35, at IE, col. 2 .

47. In order to have these profits treated as capital gain, a building owner must structure the sale so that it does not coine within the Internal Revenue Code definition of property "held by the taxpayer primarily for sale to customers in the ordinary course of his trade or business." I.R.C. $\S 1231(b)(1)(B)$ (einphasis added). See Anderson \& Cody; Lippinan, Income Tax Considerations in Conversions of Residential Rental Building to Cooperative or Condominium Ownership, in CoNdominium and Cooperative Conversions 235 (1979). See also Shapiro, Commercial Condominiums: Significant Tax Benefis Possible if Properly Structured, 41 J. TAX 46 (1974).

In Malat v. Riddell, 383 U.S. 569 (1966), the Court explained the policy behind section 1231(b)(1)(B): "The purpose of the statutory provision with which we deal is to differentiate between the 'profits and losses arising from the everyday operation of a business' on the one hand ... . and 'the realization of appreciation in value accrued over a substantial period of tine' on the other." Id. at 572 (citations omitted). Some of the factors the courts may consider are the following:

(1) the nature and purpose of the acquisition of the property, (2) the duration of ownership, (3) the extent and nature of the taxpayer's efforts to sell the property, (4) the number, extent, continuity and substantiality of the sales, (5) the extent of the subdividing, developing and advertising activities used to increase sales, (6) the use of a business office for the sale of the property, (7) the character and degree of supervision or control exercised by the taxpayer over any representatives selling the property, and

(8) the time and effort the taxpayer habitually devotes to the sales activities.

Lippman, supra at 238. See Anderson \& Cody 897. Many authorities believe that a landlord who converts a building one unit at a time is likely to be taxed on the gains at the ordinary imcone rate, sometimes as high as 70\%. Lippinan, supra at 239; Robbins, Condominiums Heading East From Chicago, N.Y. Times, Apr. 8, 1979, \& VIII, at 4, col. 2. Other authorities beheve that conversion by the landlord could be viewed as a "liquidation of an investunent" and thus taxed at the capital gains rate. See Heller Trust v. Commissioner, 382 F.2d 675, 680 (9th Cir. 1967); Municipal Bond Corp. v. Commissioner, 341 F.2d 683, 689 (8th Cir. 1965); Anderson \& Cody 894-97; Lippinan, supra at 241-44; Shapiro, supra.

48. I.R.C. § 1221(1).

49. Chicago Tribune, supra note 34, at 8, col. 2. 
tion, smce the quick profits on small equity investments in conversions compare favorably to those offered in time-consuming and expensive construction. In summary, in a market of strong demand, conversion allows investors and developers to make available rapidly a substantial supply of condominium units with a relatively small short-term, lowrisk investment.

\section{Effects of Conversion: A Public Policy Perspective}

\section{A. Advantages to Individuals Seeking Homeownership}

Most of the benefits of conversion for those desiring to own their own homes have been discussed. ${ }^{50}$ Principally, conversion satisfies a strong demand for condominium ownership. If conversion were restricted, this demand would not be satisfied, and prices of existing units would rise and thus force many buyers out of the market. Furthermore, converted units provide an inexpensive housing alternative in or around major urban areas, offering the benefits of homeownership to persons who might otherwise be unable to afford a home. ${ }^{51}$ When combimed with the discounts available to prior rental tenants, the appreciation factor on converted condominium umits provides a tremendous hedge agamst inflation for a homeowner and an excellent investunent.

\section{B. Advantages of Conversion for Urban Areas}

Conversion has several important beneficial effects that militate agamst its restriction. One of the primary benefits of conversion is that it aids in reversing the detrimental decentralization process. ${ }^{52}$ Decentralization is the process by which middle and upper socio-economic groups are encouraged to move from the city to the suburbs. ${ }^{53}$ One important imcentive fostering such movement is the tax benefits that accompany the purchase of owner-occupied housing. As long as most inner city housing is rental property, middle or upper income people

50. See notes 12-31 supra and accompanying text.

51. Condominium conversion may, for example, help satisfy the increased demand for home ownership by blacks, which is growing at a rate greater than demand by the population at large. See Brimmer, Homeownership and Condominium Conversions, BLACK ENTERPRISE, Aug. 1979, at 55.

52. For detailed discussions of decentralization, see Success Abroad: What Foreign Cities Can Teach American Cities: Hearings Before the Subcomm. on the City of the House Comm. on Banking, Finance \& Urban Affairs, 95th Cong., 1st Sess. 511-78 (1977) (statement of George A. Reigeluth); Note, From Urban Decay 10 New Construction and Rehabilitation: Housing in the District of Columbia, 27 CATH. U.L. REv. 579, 583-94 (1978).

53. See Success Abroad Hearings, supra note 52, at 517-20 (statement of George A. Reigeluth). 
seeking to own housing inust nove to the suburbs or the urban fringe to obtain these tax advantages. ${ }^{54}$

The detrimental effects of such decentralization are numerous:

[D]ecentralization can and often does cause a relative decline in the ability of the central cities to pay for the provision of public facilities. If, as has been the case in the U.S., families leaving the central city are younger, better educated, better trained and have higher incomes than the reinaining population, the central cities will usually suffer as a consequence of this outmigration. It will becoine inore difficult for these cities to pay for public services with declining revenues. The remaining elderly, low income population may also create additional service demands. Property values may fall and inaintenance investment decline. As a result, urban blight and inner city decay spreads and further encourages the imcome and racial segregation which typifies many U.S. cities. 55

It is often stated that condominiuin conversions have "sparked a backto-the-city movelnent ainong families," 56 aiding in the reversal of decentralization. Thirty percent or nore of converted condominium dwellers are estimated to have noved to their city hoines from the suburbs. ${ }^{57}$ As middle and upper income households return to the city to live in converted condominium units, revenues increase, cities stabilize, and the city's ability to provide essential services improves. When the condominiuun conversion takes place, real property tax revenues increase as a result of assessment differentials between the former rental buildings and the converted units. ${ }^{58}$ Soine sources estimate that the increases in tax revenues are three to four times the preconversion revenues. ${ }^{59}$ These increased tax revenues can provide an important source of funds to help tenants harned by the conversion process, and are an additional source of aid to cities facing rising costs due to inflation. ${ }^{60}$

\footnotetext{
54. See notes 15-21 supra and accompanying text.

55. Success Abroad Hearings, supra note 52, at 563-64 (statement of George A. Reigeluth).

56. Turpin, supra note 31 , at 26 , col. 1.

57. $I d$.

58. The following statement describes the tax revenue problems associated with rent controlled rental properties:

In the long run, the value of a property is a function of the mcome derived from it. Not atypically, the market values rental buildings at a multiple of their incoine; a new garden apartment development might sell for six times the rent roll, an older but still middleincome building at four or five times the rent roll.

As controls prevent a structure's rent roll froin rising to its free market potential, the building's inarket value is reduced. Thus, assessinents-and taxes-on the structure are reduced by equivalent amounts. The community foregoes tax revenue equivalent to 20 30 percent of the gap between free and controlled rents.

Rental Accommodations Hearings 330 (statement of Elizabeth Brody and George Sternlieb).

59. See Cafritz, supra note 11, at 15, col. 2. In 1976 the District of Columbia stood to gain real property tax revenues in an amount estimated at 2.3 times the preconversion revenues. Rental Accommodations Hearings 325.
}

60. "It is striking, for example, that given New York City's fiscal troubles (due, in part, to a 
Another significant benefit of the condominium conversion process is its rehabilitative effect on the city's physical housing stock. Many physical improvements are made on older rental buildings during conversion. Members of the condominium development profession argue that "new capital imvestment effectively recycles these properties for another 10 to 20 years. This replenishment of the existing housing stock is essential because high construction costs and the fear of controls have chilled new apartnient construction ...."61 Rehabilitation in the form of condominium conversions could save unany dwelling units that would otherwise be lost to abandonment or demohtion. ${ }^{62}$

Condominium conversions also help revitalize blighted and decaymg neighborhoods. ${ }^{63}$ Three mterrelated factors are blamed for deterioration of nuany residential rental areas and publicly-assisted rental housing projects: "the pliysical deterioration of the property, a lack of commitment on the part of the residents because they are not owners, and no structure for self governance." 64 Condominium conversions affect all three areas of concern: "Tlie immediate neighborliood benefits, because residency in a condormimum is no longer transient im nature. The interests of lomeowners and condominium owners are relatively identical. New resident apartment owners have a vested, long-term imterest in the social and political fabric of their neighborhood."65

A simgle restoration can often result in the revitalization of an entire neighborliood and even surrounding neighborhoods. Many small development firms become attracted to sucli areas because the conversions create new business opportunities. ${ }^{66}$ Noted examples of such re-

shrinking real estate tax base and wholesale abandonment of buildings), not a single privately sponsored cooperative or condoininiuin project has defaulted on its real estate tax obhigations." Rọhan 599 n.63. In fiscal year 1974-1975, New York City tax delinquencies were estiunated at $\$ 220$ million; approxinately 35,000 housing units were being abandoned per year. Rental Accommodations Hearings 328.

61. Cafritz, supra note 11, at 15, col. 1 .

62. It is estimated that approximately 20,000 apartment units are lost in Chicago each year through demolition, even though the units inight have been saved by rehabilitation. McCabe, Condo Forces Join to Battle Byrne Proposal, Chicago Tribune, June 28, 1979, § N6, at 6, col. 2. See Wood, supra note 8 , at 17 , col. 1.

63. See, e.g., Chicago Tribune, May 27, 1979, § N14, at 2, col. 2 (condouniniuun conversion process credited with revitalizing formerly blighted area of Chicago's uptown area partly because of incrcased resident stability and physical building improvenıents).

64. Chicago Tribune, July 23, 1978, $\$$ N12, at 2, col. 1 (quoting an executive director of the Community Association Institute).

65. Cafritz, supra note 11, at 15, col. 1-2; see Chicago Tribune, supra note 64, at 2, col. 2.

66. Chicago Tribune, supra note 63, at 2, col. 2. The treasurer of Chicago's Association for Neighborhood Rehabilitation has stated: "We've all felt the effect a single restoration has had on a city block or neighborhood. . . . The ripple of confidence and commitinent speaks to other neighborhoods, local business and neighborhood institutions." McCabe, supra note 62, at 6, col. 2. See also Donsky, supra note 31 , at 26 (revitalization aids in attracting business, "particularly 
vitalization include the Quincy Market and Waterfront area in Boston, Oldtown Mall in Baltimore, and Society Hill in Philadelphia.67

In summary, condominium conversions benefit urban areas by revitalizing the deteriorating housing stock, reversing decentralization, increasing cities' tax bases, and adding stability to decaying neighborhoods. As stated by condominium authority Professor Patrick Rohan, "[T]here is today a strong . . . interest in encouraging such conversions: it is increasingly apparent that occupier-ownership in the form of . . . condominiums offers the best long-range solution to the problem of urban decay." 68

\section{Disadvantages of Conversion}

Although condominiuin conversions offer clear benefits, they also create difficulties. Foremost among these difficulties is tenant displacement, a hardship that falls nost heavily upon the poor and elderly. In addition, each conversion removes more rental units from the narket, with the result that more displaced tenants are searching for fewer rental opportunities. This reduction in rental units also creates problems for transient residents such as students. ${ }^{69}$ Furthermore, as older buildings are renovated and neighborhoods are generally improved, dwelling unit prices increase, thus removing an important source of low-cost housing for lower income households.

1. Reduction of rental stock. One of the two most publicized disadvantages associated with the conversion process is the resulting decrease im rental housing stock. "A rental unit shortage is exacerbated by conversions. Each conversion further diminishes the supply of rental umits available, and this in turn leads to ... [s]ignificant relocation problems . . . when the tenant is faced with finding a comparable rental unit from rapidly diminishing supply."70 In many major cities across the country, vacancy rates in the rental housing inarket are extreinely low. ${ }^{71}$ A severe loss of rental umits in a city is clearly undesirable, as rental opportunities are needed by students, young adults, the

finns catering to the middle classes [that have] shown renewed interest in opening downtown stores, especially in fancy inalls").

67. Donsky, supra note 31 , at 26.

68. Rohan 599. In 1978 it was reported that the Community Association Institute, a Washington, D.C., based organization, was awarded a $\$ 25,000$ grant from the Ford Foundation to develop techniques for using the condomimium conversion process to preserve and revitalize urban areas. Chicago Tribune, supra note 64 , at 2 , col. 1.

69. Wood, supra note 8, at 17, col. 1 .

70. C. Rhyne, W. RhyNe, \& P. Asch, Municipalities and Multiple Residential HousING 62 (1975).

71. The vacancy rate is the percentage of unoccupied rental housing units. A vacancy rate of five percent means that $95 \%$ of a city's rental units are occupied. 
elderly, and the poor, who are unable to make large commitments of resources over long periods of time. ${ }^{72}$

While conversion of rental units to condominiums does obviously decrease the number of rental units, conversion is not the primary cause of the severe shrinkage of the rental market. ${ }^{73}$ The growing unprofitability of maimtaining rental units is a significant reason for the reduction in supply. ${ }^{74}$ Unprofitability leads not only to conversion, but also to abandonment and deinolition. Conversion, like abandonment and demolition, is a syinptom of the ailing rental market.

The dwindling supply of rental units caused by abandonments, demohtion, decay, and conversions is exacerbated by the decrease in private construction of new rental units. ${ }^{75}$ Factors behind this decline in new construction include soaring construction costs and skyrocketing interest rates. ${ }^{76}$ As a result inost new multifamily rental housing construction is government subsidized. ${ }^{77}$ Rent control also plays an important role in inhibiting new construction. ${ }^{78}$ The negative effects of rent control are evident in alinost every area where the system has been imposed. Shortages of rental housing are common, apartment maintenance becomes less profitable and is deferred as revenues diminish, and private construction of new rental units is discouraged. ${ }^{79}$ Milton Fried-

72. Note, Conversion of Apartments to Condominiums and Cooperatives: Protecting Tenants in New York, 8 U. Mich. J.L. REF. 705, 716 (1975). See also Chicago Tribune, Feb. 24, 1979, § N1, at 10 , col. 1 .

73. A recent survey conducted by Advance Mortgage Corp. and Citicorp Real Estate, Inc. found that conversion has had a significant impact on the rental housing market in only a very few cases. The study reports, for example, that since 1974 the District of Columbia has lost only three to five percent of its rental stock through conversions and that the Washington suburbs have lost only 10\%. 6 Hous. \& DEv. REP. (BNA) 1094 (1979).

74. See notes 32-38 supra and accompanying text.

75. Jay Janis, Undersecretary for the Department of Housing and Urban Development, has described the conventional multifanily rental housing market as "in serious trouble." He predicted that when the data were complete, new construction without some form of government subsidy would hikely fall below 100,000 units for 1979. 6 Hous. \& DEV. REP. (BNA) 1152 (1979).

76. Interest rates on construction loans range from prime to $41 / 2 \%$ above prine. The specter of high interest rates has an adverse effect on new construction. The Commerce Department has predicted that the year-end data for 1979 would show a decline in new construction of approximately nine percent for the year. Ramirez, supra note 12, at 1, col. 6 .

77. Lawrence Simons, Assistant Secretary for Housing in the Department of Housing and Urban Development, predicted that as much as $75 \%$ of multifamily rental housing starts for 1979 would have some form of government subsidy. 6 Hous. \& DEv. REP. (BNA) 703 (1978).

78. See Friedman \& Stigler, Roofs or Ceilings? The Current Housing Problem, in RENT CoNTROL 99-100. See also Rental Accommodations Hearings 32.

79. Utt 90. For a general discussion of rent control and its effects, see RENT CONTROL; M. LETT, RENT CONTROL (1976).

Rent control has also had a serious effect on new construction, thus exacerbating rental housing shortages, in countries such as France, Great Britain, and Sweden. In Paris, when new units were brought under rent control, new construction virtually ceased for 12 years until new units 
man has summed up the situation:

Rent ceilings do nothing to alleviate this [housing] shortage. Indeed, they are far inore likely to perpetuate it: the implications of the rent ceilings for new construction are ominous. ... New construction must therefore be disappointingly sinall in volune unless (1) an industrial revolution reduces building costs drainatically, or (2) the government subsidizes the construction industry. ${ }^{80}$

2. Tenant Displacement. The most serious and most widely publicized adverse effect of condominium conversion is the displacement of tenants who either cannot afford to buy, or choose not to buy. ${ }^{81}$ This problem is particularly acute for the poor and elderly, who often live im the well-located old, but substantial, buildings that are prime targets for conversion. ${ }^{82}$ Many of these people cannot make the downpayments necessary to purchase their apartments. This is particularly true of the elderly, who often have sufficient incomes to pay controlled rents, but who cannot provide the large cash outlays necessary for a purchase. ${ }^{83}$

Studies imdicate that most displaced tenants are able to find alternative housing within a reasonable ainount of time after conversion, ${ }^{84}$ sometimes only a short distance from the converted property. ${ }^{85}$ The

were decontrolled. In Great Britain, in the controlled sector, private rental units account for only $14 \%$ of the market. In Sweden, the government has had to produce $40 \%$ of the market's rental units in order to compensate for the growing decline of private construction. Utt 88-89. See H. Wolman, Housing and Housing Policy in the U.S. ANd the U.K. (1975).

80. Friedman \& Stigler, supra note 78 , at 99.

81. It is estimated that between 1976 and 1978 more than 2,000 tenants were evicted fronı their apartments due to condoninium conversions. Lindsey, Rent Controls Gain in the Nation as a Cause Pressed by the Young, N.Y. Times, Apr. 15, 1979, § 1, at 1, 20, col. 3. One conversion authority estimates that in "middle imcome" projects approximately $30 \%$ of existing tenants will purchase their units. In a luxury building, tenant purchases could run as high as $70 \%$. Schwab, supra note 14 , at $18-19$.

82. Senate Hearings, supra note 29, at 308 (statement of Nelson H. Cruishank, President, National Council of Senior Citizens).

83. Comment, supra note 40 , at 984 (quoting the former New York Attorney General). In addition, many apartment renters who have been living in the city for a substantial number of years feel that it is unfair to be forced to choose between buying or moving from the city. Camp, supra note 36, at 5, col. 1; Wood, supra note 8, at 17, col. 1 .

84. A survey by Advance Mortgage Corp. and Citicorp Real Estate, Inc. found that even in the tight Washmgtou, D.C., rental inarket, hardly any cases were reported in which tenants were unable to find housing within the grace period before they had to inove. 6 Hous. \& DEv. REP. (BNA) 1094 (1979).

85. One report showed that displaced Washington, D.C., teuants generally found alternative housing in the District of conparable size to the converted unit without incurring large increases in rental expenses. An examination of the intracity migration pattcrn reveals that a substantial amount of movement and many neighborlood shifts oceurred, but that virtually all of the tenants who remained in the District (88\% of the sample) did not lave to move more than $21 / 2$ miles from their previous units. These tenants chose the new units on the basis of accessibility and appeared satisfied. Rental Accommodations Hearings 322-23. 
availability of housing should not, however, obscure the very real problems caused by displacement. Displacement poses economic hardships for poor and elderly tenants, since the rents for alternative housing may be far higher than for the converted property. Each new conversion coinpounds the problein, as it decreases the rental unit supply, already reduced by abandonment and demolition. Increasing numbers of displaced tenants then coinpete for dwindling numbers of rental units, pushing rents even higher. Furthermore, displaceinent may cause significant psychological difficulties, particularly for elderly persons forced to leave buildings or neighborhoods where they have hived for long periods. ${ }^{86}$ Cities and states considering the conversion phenomenon should be aware of the difficulties faced by poor and elderly tenants and should design legislative responses that address these problems.

\section{Alternative Approaches to Conversion Regulation}

\section{A. Present Responses.}

In response to the recent increase in condominiuin conversions, and the effects that accompany the conversions, several states and cities have enacted provisions regulating condominium construction. This portion of the Comment will discuss some of the regulatory schemes enacted to deal with the conversion phenomenon. The regulations discussed are by no means exclusive; they do, however, represent the mainstream in conversion regulation and illustrate the inanner in which inost states and cities have chosen to deal with conversions.

1. Prohibitions. Many state and local governments are enacting moratoriums on condominiuni conversions. ${ }^{87}$ These moratoriuins are

86. See Cafritz, supra note 11 , at 16 , col. 1. "Often the tenant will have established roots in the community and a forced move creates undesirable psychological effects." C. RHYNE, W. RHYNE \& P. ASCH, supra note 70, at 62. In a study by the National Council of Senior Citizens of elderly displaced tenants of low and inoderate mcome, $92 \%$ of those who responded to a questionnaire found it harder to see their families after moving, $81 \%$ found it harder to get to churcl, $70 \%$ found it harder to see their doctors, and $45 \%$ experienced ill health effects (often described as depression, mental distress, or anxiety). Senate Hearings, supra note 29, at 309-10.

87. E.g., Chicago (40-day moratorium), Chicago, Ill., Journal of the City Council of Chicago, Ill. 9807-9808 (Mar. 21, 1979); Montgomery Couuty, Md. (120-day moratorium enacted in July 1979), Montgomery County, Md., Bill No. 47-79, § 3(a)-(b) (July 20, 1979); Washington, D.C. (successive moratoriums, the last of which was a 90-day moratorium enacted in August 1979), Third Eniergency Cooperative Regulation Act of 1979, D.C. Act 3-79 (Aug. 3, 1979); Philadelphia (18-month moratoriunı enacted Sept. 27, 1979), Philadelphia, PA. Code ch. 9-1200, § 9-1206 (1979); Pappas, Philadelphia's Ban on Condominiums Runs Into Problems, Wall St. J., Oct. 2, 1979, at 20 , col. 3. In addition, Representative Benjamm Rosenthal has introduced a bill in Congress proposing a three-year national moratorium on condomimium conversions, H.R. 5175, 96th Cong., Ist Sess. (1979). A moratorium was recently rejected in Boston, 7 Hous. \& DEV. REP. (BNA) 227 (1979). 
imposed in response to perceived emergency situations, ${ }^{88}$ and are generally effective for periods of 30 to 120 days. ${ }^{89}$ Although most conversion moratoriums are too recent to have been tested in the courts, at least one decision, by Judge McGarr in the Federal District Court for the Northern District of Illinois, held that a total mortatorium on conversions amounts to a taking of property without due process of law. ${ }^{90}$ Judge McGarr overturned the Chicago moratorium, stating that the buying and selling of property is a fundamental constitutional right.91

88. For example, a Cambridge, Massachusetts, ordinance places an indefinite prohibition on conversions tied into vacancy rates and numbers of rental units. Cambridge, Mass., Ordinance 926 (July 19, 1979). It was enacted in response to a "serious public einergency." Id. A Marin County, California, ordinance allows local planning and supervisory boards to prohibit conversions whenever a housing einergency exists. MARIN CounTY, CALlF., Ordinance ch. 20-72 $\S 20.72 .053$ (1977). Under the Marin County ordinance, a lousing einergency exists whenever the total number of rental units accounts for less than $25 \%$ of the total number of units on the market, or when the rental vacancy rate falls below five percent. Id. $\$ 20.72 .053(\mathrm{a})$-(b). The ordinance powers were exercised at least twice in the summer and fall of 1979. 7 Hous. \& DEv. REP. (BNA) 227 (1979). For a discussion of the situation in Washington, D.C., see Caunp \& Whitaker, City's Emergency Condominium Law Overturned, Washington Post, Oct. 20, 1979, § B, at 1, col. 1.

89. See, e.g., ordinances discussed in note 87 supra.

90. Chicago Real Estate Bd. v. City of Chicago, No. 79-C1284 (N.D. Ill. Apr. 3, 1979).

91. Id. Judge McGarr also stated that the fact that conversions can be and are being regulated, does not mean they can be prohibited entirely, even for a short period of time. Id.

Recently, the Washington, D.C., inoratoriuin was overturned as an abuse of the einergency power. Washington Home Ownership Council v. District of Columbia, No. 10624-79 (D.C. Super. Oct. 19, 1979). The court stated that "successive enactment of substantially the same substantive provisions of law th[r]ough the einergency power . . . is . . . unlawful." Id. at 16. Judge Revercounb defined an emergency situation as "circumstances . . . constituting an unforeseen occurrence or condition calling for immediate action to preserve the public peace, health, safety, welfare or inorals." Id. at 11. See Cainp \& Whitaker, supra note 88, at 1, col. 1. Judge Revercomb ruled that the moratoriun could stay in effect until the appellate court could rule on its validity. Before the appeal, on Noveınber 23, 1979, Mayor Barry signed an emergency bill into law that extended the moratoriun for another 90 days.

Under their pohice power, the states inay regulate the use of property to promote the public health, safety, welfare, and morals. This regulation generally does not annount to a taking of property (the exercise of eminent doinain), which would require the payment of reasonable coinpensation. See Chicago, Burlington, \& Quincy R.R. v. City of Chicago, 166 U.S. 226 (1897) (holding that due process requires just compensation by the state for an exercise of the eininent domain power). See also J. Nowak, R. Rotunda, \& J. Young, HANDBOok ON ConstituTIONAL LAW 437-40 (1978). The key issue in the area of condominium moratoriuns is thus whether regulation alnounts to a taking of property without coinpensation. If so, it violates the due process clause of the Constitution. See Michelinan, Property, Utility, and Fairness: Comments on the Ethical Foundations of "Just Compensation" Law, 80 HARv. L. REv. 1165 (1967). This concept was recognized by the Supreme Court in Pennsylvania Coal Co. v. Mahon, 260 U.S. 393 (1922): "While property may be regulated to a certain extent, if regulation goes too far it will be recognized as a taking." $I d$. at 415 .

In Euclid v. Ambler Realty Co, 272 U.S. 365 (1926), the Supreme Court considered land use zoning ordinances that a realty company claimed amounted to a taking of property without due process. Land use regulations are similar to conversion restrictions even though conversion restrictions are based on the status of the units rather than their use. The Court ruled that the ordinances protected a significant public interest in segregation of incompatible land uses and 
While the government has a duty to balance the rights of the public against a property owner's right to do with his property as he wishes, in the view of some courts, a moratoriuin simply goes too far. ${ }^{92}$

Even if moratoriums are permissible, they may not be wise. Prohibitions against conversions reduce the supply of condominium umits on the inarket. If deinand remains strong, prices of existing units rise. The result is that many who could own homes only through condominium conversions are forced into the already strained rental market.93 Finally, an absolute prohibition against condominium conversions prevents society from enjoying the benefits of conversion.

2. Eviction Regulations. Some state and local governments have dealt with tenant displacement by regulating the eviction of tenants froin converted apartment buildings. In May 1979, the town of Brookline, Massachusetts, passed an amendment to an existing ordinance giving tenants in a converted apartment building the right to remain in the apartment virtually indefinitely unless they commit specified violations. ${ }^{94}$ The 1979 amendment eliminated provisions that allowed a landlord to recover possession for his own personal use or the use of a close relative, subject to a six-month grace period for the tenant in hardship cases. ${ }^{95}$ The unamended ordinance regulated eviction by the

were thus a valid exercise of the police power. Id. at 390-95. In 1962 the Supreme Court, in GoIdblatt v. Town of Hempstead, 369 U.S. 590 (1962), delineated the modern test. Goldblatt dealt with a zoning ordmance restricting certain quarry operations. The Court upheld the ordinance while announcing a two-part test to determine whether a land use regulation is valid: first,

- whether "the interests of the public . . . require sucl imterference; and, second, [whether] the means are reasonably necessary for the accoinplishment of the purpose, and not unduly oppressive upon individuals." Id. at 594-95 (quoting Lawton v. Steel, 152 U.S. 133, 137 (1894)) (emphasis added). The Goldblatt rule seems to require regulators to adopt less restrictive regulations if any are available. This rule is reflected in Judge McGarr's recent conversion moratoriuin decision. Chicago Real Estate Bd. v. City of Chicago, No. 79-C1284 (N.D. 1ll. Apr. 3, 1979). See generally J. NowaK, R. RotuNDA, \& J. Young, supra; Michelman, supra. Cf. Grace v. Town of Brookline, — Mass. -, 399 N.E.2d 1038 (1979) (upholding ordinance prohibiting eviction of tenants in condoininium conversions; conversion was not prohibited simce it was permissible if tenants choose to buy or vacate voluntarily). See notes 94-104 infra and accompanying text.

92. See Chicago Real Estate Bd. v. City of Chicago, No. 79-C1284 (N.D. Ill. Apr. 3, 1979).

93. Wasliburn, Moratoriums: Pros and Con(do)s, Chicago Tribune, Mar. 18, 1979, § N14, at 1, col. 3.

94. Brookline, Mass., By-laws, art. XXXVIII, \& 9 (as amended May 7, 1979). Violations specifled by the statute include failure to pay rent, id. $\$ 9(\mathrm{a})(1)$; violation of a convenant, $i d$. $\S 9$ (a)(2); maintaining a nuisance, id. $\$ 9(\mathrm{a})(3)$; using the unit for an illegal purpose, id. $\S 9(\mathrm{a})(4)$; refusal to execute a lease renewal, $i d . \S 9(\mathrm{a})(5)$; refusal of access to the landlord to make necessary repairs, id. $\$ 9(a)(6)$; and leaving in residence at the end of the lease term a subtenant not approved by the landlord, id. $\$ 9(\mathrm{a})(7)$.

95. Id. \&9(a)(8). Under the 1979 amendment, the landlord may evict the tenant to recover possession for his own personal use, "except that no action shall be brought under this paragraph to recover possession of a condominium unit from a tenant who has oceupied the unit contimuously since a time prior to the recording of any unaster deed for the condominium." Id. 
landlord only; thus, a landlord could sell a unit as a condominium to a purchaser, who, as the new landlord, could then sue to evict the tenant and recover possession for his own personal use, subject to the sixmonth grace period. ${ }^{96}$

In Grace v. Town of Brookline, ${ }^{97}$ the Supreme Court of Massachusetts recently rebuffed due process and equal protection attacks on the pre-amendment ordinance. Although the amended ordinance has not yet been tested, language in Grace indicates that the Massachusetts Supreme Court would uphold it. ${ }^{98}$ It should be noted that the Brookline ordinance applies only to rent-controlled units. ${ }^{99}$

It is clear that the Brookline ordinance will drastically reduce, if not stop, condominiuin conversions. 100 Thus, the ordinance has the same practical effect as a moratorium. ${ }^{101}$ In addition, the ordinance may have the unintended effect of encouraging landlords to give large settlements to tenants in order to induce them to leave. ${ }^{102}$ Such settlements could result in unjust enrichment for stubborn tenants for whom 1noving poses no serious burdens. ${ }^{103}$ The ordinance could also beconie a prime source of friction between such tenants and landlords, ${ }^{104}$ or

\footnotetext{
96. See Grace v. Town of Brookline, - Mass. - , 399 N.E.2d 1038 (1979).

97. Id.

98. In upholding the pre-ainendment ordinance the court stated:

It is clear, however, that the major thrust of the act was directed at the need to control ... the "substantial and increasing shortage of rental housing accommodations" which most severely afflicts "families of low and moderate income and elderly on fixed incomes." See c. 843 \& 1. By retarding the pace of condominium conversion the by-law amendments further this purpose. In doing so, moreover, they fairly accommodate the imterests of building owners and condoininium developers and purchasers. They do not deprive the landlords of their reasonable profits. Nor do they preclude condominium conversions altogether. Conversion is permissible and may proceed unimpeded when the tenant chooses to buy the unit or vacates voluntarily.
}

399 N.E.2d at 1043 (einphasis added).

99. Thus, the ordinance covers approximately 11,000 rent-controlled units, and excludes approximately 5,500 noncontrolled units. 6 Hous. \& DEV. REP. (BNA) 1201 (1979).

100. Id. It is interesting to note that, like most moratoriuins, the amended ordinance was passed "for the purpose of obtaining relief fron [conversions] so that there is time for the coinınunity to study and consider long term solutions for this housing problem . . . Resolution accompanying amendment of Brookline, Mass., By-laws, art. XXXVIII, $\$ 9$ (as amended May 7 , 1979).

101. See notes $87-93$ supra and accompanying text.

102. See, e.g., Beach, The Condo Conversion Game: A Battle of Wits for High Siakes, Washington Post, Mar. 18, 1979, $\S \mathrm{D}$, at 1 , col. 2. Settlements to holdout tenants run as high as $\$ 3,200$ per tenant. Id. 3 , col. 4 .

103. With demand for condominiums so strong, developers have less reason to fear that they won't recover the cost of large tenant settlements, and with today's high imterest rates, developers are eager to put their units on the market and pay off their construction loans. Paymg a stubborn tenant a couple of thousand dollars can almost begin to look Id.

like a bargain.

104. See, e.g., Brelemeiar, Landlord Wrecks Boiler, Then Told to Supply Heat, Washington Post, Oct. 19, 1979, § C, at 8, col. 1 . 
between those tenants who wish to buy and thus favor the conversion and those who do not wish to buy yet refuse to move. Finally, like the moratorium, the eviction regulation ignores the positive aspects of conversion.

3. Tenant Purchase Requirements: The New York Approach. New York City is the prime example of a city suffering from deficiencies in the urban lousing market. With costs constantly imcreasing, and rent control or stabilization in effect for most units, landlords have turned to large-scale demolition, abandonment, and conversion. ${ }^{105}$ In response to these obvious problems, the state has enacted one of the most restrictive condominium conversion regulations short of a moratorium. ${ }^{106}$ Under the New York regulations, a landlord inay not proceed with a plan to evict tenants ${ }^{107}$ unless a minimuin of thirty-five percent of the tenants occupying rental umits at the time the conversion plan is accepted for filing agree to purchase units. ${ }^{108}$ In addition, new regulations prohibit the eviction of any elderly person ${ }^{109}$ with an amual incoine under $\$ 30,000$ who has lived in the building for at least two years as a primary resident. ${ }^{110}$ The purpose of this tenant purchase requirement is to protect tenants.

against excessive pricing and unfair terms. ... [T] The requirement of sales to at least $35 \%$ of the existing tenants within one year to make the plan effective enables the tenants to organize into a strong bargaining unit. A well organized group of tenants can ... make counter offers and . . . either negotiate acceptable terms or defeat the sponsor's plan."11

The practical effect of the tenant purchase requirement is to inake con-

105. See Olsen, Questions and Some Answers About Rent Control: An Empirical Analysis of New York's Experience, in RENT CONTROL 145-60.

Abandonment, decay, and arson have risen to high levels. Abandoninents are about 20,000 units per year, and real estate tax delinquencies now occur at a rate of 6 percent annually, the highest delinquency rate since the 1930 Depression. In addition . . . both New York City and State have been drawn into housing production and ownership in order to compensate for the continuing decline in the availability of private, rental housing.

Utt 90.

106. N.Y. GEN. Bus. LAw \$ 352-eeee (McKinney Cum. Supp. 1979) (effective July 5, 1979; to expire July 1, 1981); see Dryfoos, Lelner, \& Sweet, Cooperative and Condominium Conversions, N.Y.L.J., Sept. 14, 1979, at 1, col. 2.

107. The landlord inay, under a noneviction plan, sell the units as they becoune voluntarily vacant. He cannot, however, evict anyone without the ininimum number of tenant purchasers.

108. N.Y. Unconsol. Laws § 55(f)(3)(c) (McKinney 1974); N.Y. GEN. BUS. LAw § 352-ceee(b) (McKinney Cnm. Supp. 1979).

109. An elderly tenant is defined as a tenant at least 62 years old. Id. $\S 352$-eeee(1)(e).

110. Id. This statute was upheld against an equal protection challenge in Reiner-Kaiser Assocs. v. McConnachie, N.Y.L.J. Aug. 27, 1979, at 13, col. 1 (Queens County Civ. Ct.). See Eisen, 9 on Council Back Bill for Tough Condo Law, Washington Post, Nov. 14, 1979, § C, at 1, col. 1 (District of Columbia proposal for hifetime tenancies for elderly tenants).

111. Senate Hearings, supra note 29, at 284. See Note, supra note 72 , at 711. 
version much easier for landlords of luxury buildmgs 112 than for landlords of rent-controlled buildings. In buildings in which rent control is keeping rent prices substantially below market prices, tenants will most often be unable or unwilling either to purchase or to move and pay substantially higher rents, thus making conversion difficult, if not impossible. ${ }^{113}$

Under the present restrictive conversion regulations, many landlords in New York will allow their rental buildings to deteriorate, or else simply abandon them. ${ }^{114}$ Furthermore, like eviction regulations, purchase requirements can become a prime source of friction between landlords and tenants, and between tenant factions. ${ }^{115}$ The additional restrictions, giving virtual life tenancies to elderly tenants, may also have the ironic effect of making rental housing less available for the elderly, since landlords with long term conversion plans may be unwilling to rent to elderly persons. ${ }^{116}$

Finally, any government agency that deals with restrictions on property rights should be sensitive to striking the proper balance between a landlord's property rights and the legitimate necessity of protecting tenants, and should avoid unnecessarily tipping the balance to one side. Unlike the Brookline ordimance, which regulates eviction and indirectly affects the landlord's right to convert his property, the New York regulations directly affect a landlord's right to convert, subjecting the decision to approval of the tenants. Such regulation is of questionable constitutionahty. In Rothman v. Borough of Fort Lee, ${ }^{117}$ a New Jersey superior court overturned a similar purchase percentage requirement as unconstitutionally vague and unjustified when applied to luxury apartments im a rent emergency situation. ${ }^{118}$ However, in RenierKaiser Associates v. McConnachie, ${ }^{119}$ a state court recently upheld the New York regulations in the face of an equal protection attack.

4. Tenant Consent and Vacancy Rate Formulas. The District of Columbia law concerning condominium conversions, when not preempted by a moratorium, presents a more thoughtful approach to regulating conversion, but still includes some shortsighted responses to the

112. See note 81 supra.

113. See Note, supra note 72 , at 714-16.

114. 7 Hous. \& DEv. REP. (BNA) 138 (1979).

115. See notes 102-04 supra and accompanying text.

116. Oser, Protecting Elderly Tenants in Apartment Conversions, N.Y. Times, June 29, 1979, § A, at 17, col. 2; see Washington Post, Nov. 16, 1979, \& A, at 20, col. 1.

117. No. L21679-73 P.W. (Super. Ct. Bergen County, N.J. June 14, 1974).

118. Id.; $c f$. Cainp \& Whitaker, supra note 88 , at 1 , col. 1 (discussing D.C. emergency condominuin legislation).

119. N.Y.L.J., Aug. 27, 1979 at 13, col. 1 (Queens County Civ. Ct.). 
problem. ${ }^{120}$ The regulation allows unrestricted conversion of units if the "accommodation is a high rent housmg accommodation or if that rental unit is located in a high rent housnig accommodation."121 For those buildings not $\dot{\mathrm{n}}_{1}$ the high rent category, conversion is tied to a vacancy rate and consent formula, with conversion allowed as long as the vacancy rate is above three percent. ${ }^{122}$ If the vacancy rate is three percent or below, conversion is permitted only when "a majority of the heads of households actually residing in such housing accommodation, as of the first day of the month in which the apphication . . . is filed, have signed a written agreement consentimg to such conversion." 123 The District of Columbia regulation also allows tenants the right of first refusal to purchase their individual units or the whole property, and requires relocation and housing assistance for ehgible tenants. ${ }^{124}$

The District of Columbia approach has at least two major problems. First, the tenant consent provision is likely to inhibit condominium conversions nuuch like the tenant purchase requirements of the New York regulations. ${ }^{125}$ Like New York City, Washmgton is a rentcontrolled city. Tenants unwilling or unable to purchase their units are unlikely to consent to conversion and thus subject themselves to the discomforts and problems of noving and the likelihood of paying an increased rent after the move. ${ }^{126}$ Second, as a practical matter, the va-

120. D.C. CoDe ENCYCL. $\S \S 5-1281$ to 1282 (West Cum. Supp. 1978).

121. Id. $\S 5-1281$ (b)(1). As of October 1, 1979, the high rent floor for a two-bedroom apartment, for example, was $\$ 314$ per month. Coleman, Tighten Up Condo Law, City Urged, Washington Post, Sept. 19, 1979, § B, at 1, col. 5.

122. D.C. CODE ENCYCL. \& 5-1281(b)(1)(B) (West Cum. Supp. 1978). A Marin County ordinance bans conversions whenever vacancy rates fall below five percent. Wall St. J., supra note 30, at 31 , col. 1 .

123. D.C. CODE ENCYCL. § 5-1281(b)(2) (West Cum. Supp. 1978); see Eisen, supra note 110, at 1 , col. 1 (District of Columbia proposal to condition all conversions on a majority vote of tenants). Under a recently enacted Los Angeles, California, ordinance, conversion is denied if the vacancy rate in the particular part of town is below five percent and if it is determined that the project would liave a "significant," cumulative effect on the shortage of rental apartments there. Los Angeles, Cal., Ordinance No. 153,024 §4(f)(6) (Oct. 4, 1979). This ordinance is more flexible than a straight vacancy rate formula. This concept may also provide a superior fornm to determine whether a conversion slould be allowed when the vacancy rate is below the prescribed level. Tenant consent provisions leave the decision in the hands of one of the adverse parties. This ordinance provides for a determination unade by an independent body, which should be more equitable. The Los Angeles ordinance requires that the developer give the tenants 15 days' notice of the hearing.

124. D.C. Code ENCYCL. $\S \S 5-1268$ (b)(2), 5-1291 (West Cum. Supp. 1978). See notes 144-51 infra and accounpanying text.

125. See notes 114-16 supra and accompanying text.

126. As a meinber of the Washington office that issues certificates of eligibility for building conversion states, "We don't get too many buildings on the basis of tenant consent." Washburn, supra note 35, at 2, col. 2. A 1974 Palo Alto, California, ordimance requiring approval of twothirds of the teuants when the rental lousing vacancy rate is three percent or below has virtually 
cancy rate formulas, computed continuously, could be very costly and difficult to administer. ${ }^{127}$ In addition, such formulas fail to deal with the actual causes of low vacancy rates. Like conversion restrictions, low vacancy rates reflect severe problems in the rental housing sector. Effective legislation should be aimed at finding a solution to these low rates, not using them as a basis to restrict conversions.

5. The Conversion Tax: The Gilchrist Proposal. In order to deal with conversion problems in Montgoinery County, Maryland, Montgomery County Executive Charles Gilchrist recently proposed a conversion tax scheme designed to retard the rate of conversion without prohibitimg conversions altogether. ${ }^{128}$ Under the Gilchrist proposal, the initial seller of a condominium unit would be required to pay a one-tinie transfer tax of four percent. Umits selling for under $\$ 35,000^{129}$ would be exempt from the tax. ${ }^{130}$

The Gilchrist proposal reflects an attenipt to find a more practical solution to the conversion problem ${ }^{131}$ and offers many advantages. Gilchrist proposes that part of the money that would be raised by the tax-an estimated $\$ 4.8$ million in 1980-be used to expand the county's rent subsidy program. He also suggests that the county supplement the tax revenue with $\$ 500,000$ of county funds for cinergency lump suin payments to displaced elderly and handicapped tenants. ${ }^{132}$ The proposal would go a long way toward alleviating the "desperate hardships" 133 faced by displaced tenants. The revenues collected could also supply a source of funds for providing low-interest loans and downpayment assistance. In addition to other tenant protections, such as rights of first refusal and limited eviction grace periods, the Gilchrist proposal could offer one of the best long-range solutions to the conversion problem. ${ }^{134}$

halted conversion projects. Palo ALto, CAL. ORdinances ch. $21.40 \$ 21.40 .060$ (1974). See also Washington Post, supra note 116, at 20, col. 1.

127. Rental Accommodations Hearings 325.

128. Mansfield, County is Asked to Tax Condominium Conversions, Washington Post, Nov. 3, 1979,8 C, at 1 , col. 5.

129. Mr. Gilchrist also suggests further exemptions for certain projects in order to encourage developers to increase sales at discounted prices to low and moderate income families. $I d$.

130. Id. The tax would amount to an average of $\$ 2,400$ per unit. Montgomery County officials now estinate that the average unit sells for $\$ 60,000$. $I d$.

131. See Washington Post, Nov. 9, 1979, § A, at 20, col. 1.

132. $I d$.

133. Id.

134. See notes 157-67 infra and accompanying text. A recent proposal by Mayor Byrne of Chicago that was similar to the Gilchrist plan advocated a windfall profits tax on conversions. Under the proposal a developer would have to own a building at least three years before converting it to condoniniuins or pay a sliding scale profits tax. Even if the developer undertook conversion before owning the building for three years he would pay no profits tax if his profits 
6. Notice and Right of First Refusal: The Model Code and Uniform Act Approaches, With Local Variations. Two model acts respond to many of the problems associated with condominium development, mcluding conversion: the Model Condominium Code ${ }^{135}$ and the Uniform Condominiuin Act. ${ }^{136}$ The Uniform Condoininium Act requires the developer to give the tenants notice of the conversion no later than 120 days before they inay be required to vacate, subjeet to eviction on grounds of nonpayment of rent, waste, or conduct disturbing to neighbors. ${ }^{137}$ For a period of sixty days after notice is given, the developer must offer each tenant the first opportunity to purchase the unit on terms at least as good as those offered to the public for the following 180 days. ${ }^{138}$ The Act expressly allows a tenant to remain in possession of the unit if his or her written lease exceeds the 120-day notice period. ${ }^{139}$

The Model Condominium Code is very similar to the Uniform Condominium Act. Under the Code, however, tenants have a nimetyday right to purchase. ${ }^{140}$ In addition, the Code iniposes a three-year limit on eviction of nonpurchasers, measured from the date the conver-

were $\$ 5,000$ or less per unit. If his profits exceeded $\$ 5,000$ per unit they would be subject to a sliding scale tax for the first $\$ 7,500$ per unit plus $60 \%$ of all profits over $\$ 30,000$ per unit. The proposal also provides for notice to tenants, an eviction grace period, relocation expenses, and tenant right of first refusal. Davis, Byrne Condo Bill Unveiled, Chicago Tribune, June 2, 1979, $\S \mathrm{Nl}$, at 1 , col. 5 .

One criticisn of the Byrne plan is that it places undue emphasis on the activities of developers. Mayor Byrne has stated that her proposal is aimed not at "respectable developers," but rather at "developers who buy a building and quickly convert it to condoniniuns to obtain quick profits." Id. This statenient indicates a failure to appreciate the importance of developers to the conversion process. Developers are the economic conduit through which landlords maximize their profits. To restrict this avenue of conversion is to squeeze the landlords further, contrary to the mtent of the mayor's proposal. Developers will not commit themselves to maintaiming the building as rental property for three years. Their object is to convert and sell the units on a small personal equity investment, while trying to ninimize construction loan costs. By preventing the "quick profit" desired by condominiuin developers, conversion could be impeded. It should also be noted that a slidimg scalc profits tax may prove fairly difficult to administer. Chicago Tribune, supra note 34, at 8 , col. 1 .

A recently enacted Los Angeles, California, ordinance requires a developer who converts an apartment into condominiums to contribute $\$ 500$ per unit to a fund to help replace the rental housing stock. Los Angeles, Cal., Ordimance No. 153,024 \& 4(k)(1) (Oct. 4, 1979).

135. The Model Condornimum Code was promulgated by the Condominiun Research Institute, an imdependent body that gathers imformation in the condomimium field. The leading authority on condommium law, Patriek Rohan, is Executive Director of the Institute. Rohan 588-89.

136. The Uniform Condominium Act was promulgated by the National Commission on Uniform State Laws im August 1977.

137. Uniform Condominium Act $\S 4-110$ (a) (West 1978); see VA. CODE $§ 55-79.94$ (b) (1979).

138. Uniform Condommiun Act § 4-110(b) (West 1978); see VA. CODE § 55-79.64(b) (1979).

139. Uniform Condominium Act $\$ 4-110$ (e) (West 1978).

140. See Rohan 599. 
sion plan is first presented to the tenants. ${ }^{141}$ Most importantly, however, the Model Code prohibits local legislation, restricting regulation to the state level. ${ }^{142}$ This restriction is to insure that local governments do not subvert the state's policy of encouraging conversion whenever tenant rights are adequately protected, a policy clearly recognized by the frainers of the Uniform Act. ${ }^{143}$

Soine jurisdictions have enacted provisions similar to the inodel acts. ${ }^{144}$ A recent Montgoinery County, Maryland, ordinance contains an interesting variation of the right of first refusal concept. ${ }^{145}$ The tenants, through a tenants' organization or similar body, inust be offered first right to buy the entire property. ${ }^{146}$ They are then allowed 120 days to complete the deal. ${ }^{147}$ This requirement may give tenants significant benefits without unduly burdening the rights of property owners. ${ }^{148}$

Other local variations of the model acts require that the landlord provide displaced tenants with relocation assistance. ${ }^{149}$ In addition, an

141. Id, see Fishman v. Pollack, 165 N.J. Super. 235, 397 A.2d 1144 (L. Div. 1979); 6 Hous. \& DEv. REP. (BNA) 993 (1979) (N.J. three-year grace period).

142. See Rohan 599-600.

143. Opponents of conversions point out that the frequent result of conversions, which occur principally in large urban areas, is to displace low- and moderate-income tenants and provide homes for more affluent persons able to afford the higher prices which the converted apartinents command. Indeed, studies indicate that the burden of conversion displacement falls most frequently on low- and moderate-imcome and elderly persons. At the same time, the conversion of a building to a condoininium ownership can lead to a substantial increase $m$ property value, a result which proponents believe can be an important factor im curtailing the problem of declining urban tax bases. Proponents also pomt out that the conversion of rental units im inner-city areas to individual ownership frequently results $\mathrm{m}$ the stabilization of the buildings concerned, thus providing an important technique for use im neighborhood preservation and revitalization. This section ... seeks to balance these competing interests . . . .

Umiforn Condominium Act §4-110, comment 1 (West 1978).

144. See, e.g., VA. CODE \& 55-79.94(b) (1979).

145. Montgomery County, Md., Montgomery County Code $\S \S 11$ A-8, 11 A-9 (May 26, 1980).

146. Id. \& 11A-9(a).

147. Id. \& 11A-9(b)(1).

148. See text accompanying notes 160-61 infra.

149. See, e.g., N.J. Stat. ANN. \& 2A: 18-61.10 (West Cum. Supp. 1979) (waiver of one month's rent); Montgomery County, Md., Montgomery County Code § 11A-7(c) (May 26, 1980) (Montgomery County, Maryland, ordimance providing for relocation expenses up to $\$ 750$ to tenants found to be in financial need); Seattle, Wash., Ordinance $107707 \S 3.9$ (Oct. 2, 1978) (Seattle provision providimg for $\$ 350$ relocation assistance). See also H.R. 5175, 96th Cong., 1st Sess. 8 (1979) (providing for up to $\$ 400$ "actual and reasonable moving expenses").

In Los Angeles a recently enacted ordinance requires a developer to give tenants 120 days, notice of imtent to convert. Los Angeles, Cal., Ordinance No. 153,024 \& 4(E)(2) (Oct. 4, 1979). Tenants are given right of first refusal. Id. $\S 4(\mathrm{E})(3)$. If the tenant chooses not to buy, the ordinance gives the tenant one year to find a new apartinent. $I d$. $\S 4(G)(6)$. For tenants who are over age 62, handicapped, or parents of minor or dependent children, the ordimance provides an unhimited amount of time to find a new apartment. $\mathrm{rd}$. Those living in low or moderate cost apartments are also provided unlimited search time. Id. In addition, the ordinance requires a developer to help the tenants find new apartments and to pay a portion of the moving expenses up to $\$ 500$. $I d . \S 4(G)(7)$. The developer must also pay $\$ 1,000$ (\$2,500 for elderly and liandicapped 
Evanston, Illinois, condominium conversion regulation provides for correction of all building and fire code violations by the developer. ${ }^{150}$ To assure completion of any required corrections, the developer must establish escrow accounts and may not convey title until violations are corrected. ${ }^{151}$ The requirement that developers bring all buildings into compliance with building code regulations is necessary to protect tenants from hidden expenses if they choose to purchase; it also provides for physical rehabilitation of buildings.

In addition, the Evanston ordmance requires the developer to guarantee expressly the common areas and systems of the condominium for two years from the date he conveys the first unit of the building. ${ }^{152}$ The developer also inust expressly warrant the individual unit's "inechanical equipment" for a year from the date the unit is sold. ${ }^{153}$ The developer is required to set up escrow accounts to secure compliance with these requirements. ${ }^{154}$ Like the building code correction requirements, warranties insure that developers will provide at least minimal rehabilitation to the physical housing stock.

Despite their dissimilarities, the regulations discussed above have the common distinction of being short terin, pohtically motivated solutions to the condominium conversion problem. Each regulation atteinpts to reduce current political ammosity without giving sufficient attention to the need for an effective, long terin solution. Conversion is the symptoin of a diseased housing market; it is not the disease itself. Even if conversions are inhibited, the disease in the housing market will manifest itself $\mathrm{m}$ other forms such as decay, deinolition, and abandonment. In order to reinedy defects inherent in the housing inarket, regulations must do more than merely attempt to stamp out the syinptoins.

\section{B. An Alternative Approach.}

To be truly effective, any long term solution must address the source of the housing sector's difficulties. Preservation of the rental inarket as a source of low and moderate cost housing should be a priinary goal. Prohibitions and inhibitions of the conversion process are

tenants) in "relocation assistance" to cover relocation costs and anticipated rent increases. Los Angeles, Cal., Ordinance No. 153,592 \& 2(D)(4) (Apr. 3, 1980).

150. Evanston, Ill., Ordinance 12-0-79 $\$ 2-105(\mathrm{~A})$ (Mar. 6, 1979). The Seattle ordinance also provides for the correction of all building code violations. Seattle, Wash., Ordinance $107707 \S 4.1$ (Oct. 2, 1978).

151. Evanston, Ill., Ordinance 12-0-79 § 2-105(B)-(C) (Mar. 6, 1979).

152. Id. § 3-104(A)(1); see Uniform Condominiuin Act § 4-112 (West 1978).

153. Evanston, Ill., Ordinance 12-0-79 § 2-104(A)(2) (Mar. 6, 1979).

154. Id. \& 3-104(E). 
not effective methods for attaining this goal. Rather, increased construction and maimtenance of the current rental housing inarket should be encouraged through a system of incentives. This is not to say that all forms of tenant protection are unnecessary, for while the number of persons seriously burdened by displacement is not great, displacement does pose a significant problem for many poor and elderly tenants. Regulations should focus on protecting these people from the hardships of displacement rather than discouraging conversion per se.

1. State Preemption. Condominium conversions should not be discouraged without ample justification. As has been previously noted, local ordimances in particular tend to restrict conversions. ${ }^{155}$ For this reason, condominium legislation should be limited to the state level where local political pressures may be less oppressive. In addition, state regulations should preempt local ordinances that indirectly prevent or inhibit conversion, such as zoning restrictions based on condominium status rather than physical characteristics. ${ }^{156}$

2. Tenant Protection. Regulations that directly affect condominium conversion should focus on protecting tenants, not on restrictmg conversion, and special attention slould be given to protectimg the poor and the elderly. The Model Condominium Code and the Uniform Condominium Act both provide good foundations for regulatory schemes, but other minimum tenant protection provisions should also be imcluded.

(a) Notice and eviction grace period. A landlord should be required to give tenants sufficient notice of conversion before he can force them to vacate. ${ }^{157}$ This notice period slould be no shorter than 120 days and no longer than one year, although additional time might be considered necessary for elderly and handicapped persons. Needless to say, all tenants should be allowed to remam in possession until their written leases expire. In addition, the landlord should be prohibited from increasing rent or decreasing vital services sucls as heat, water, and electricity during the grace period. Otherwise, landlords might utilize such unethical practices to force tenants to vacate.

(b) Relocation assistance. Unplaumed and unanticipated moves are often expensive and time-consuining. When tenants are forced to vacate their homes to accommodate a developer, they should be com-

155. See, e.g., Zussman v. Rent Control Bd., 367 Mass. 561, 326 N.E.2d 876 (1975); City of Euclid v. Royal Am. Corp., No. 34018 (Ohio Ct. App. Aug. 21, 1975) (termination of trash collection from condominiums), cert. denied, No. $75-947$ (Ohio Sup. Ct. Dec. 5, 1975), cert. denied, 425 U.S. 966 (1976); Rohan 592 n.25.

156. Rohan 591-92, 599-600.

157. See notes $137-39$ supra and accompanying text. 
pensated for their expenses. At a minimum, regulations should require developers to reimburse displaced tenants for reasonable moving expenses, ${ }^{158}$ including an allowance for costs incurred in searching for new housing. The maximum amount allowed for such expenditures should be flexible, but high enough to cover all reasonable costs. Only those tenants who inove to reasonably proximate areas, however, sliould be eligible for relocation expenses. ${ }^{159}$

(c) Purchase options. Tenants sliould be given first option to purchase their individual units. ${ }^{160}$ Such options prevent the necessity of moving if tenants are able and willing to purchase their own units, and do not burden the developer since he may set the price. A first option to purchase slould remain open for a period of approximately ninety days. If the tenant declines to purchase the unit, there should be a 180-day period during which the developer is prohibited from offering the unit for sale to outside purchasers on teruns better than those offered the outgoing tenant.

The landlord slould also be required to offer the tenants the first opportunity to buy the entire property. If the tenants and landlord can reacl an agreement for the sale of the whole building, the landlord benefits no less than if he sells the building to an outsider. For the tenants, an opportunity to buy the entire building directly from the landlord results in significantly lower purchase prices for their individual units. In a sense, they have the opportunity to buy their units at the wholesale rather than the retail price. In addition, purchasing tenants can realize a profit on the sale of the unpurchased units to outsiders, and thus be better able to finance the acquisition of their own units. ${ }^{161}$

(d) Warranty requirements and correction of building code violations. Since rehabilitation is a major benefit associated with the conversion process, property improveinent should be encouraged. ${ }^{162} \mathrm{~A}$ minimum improvement is guaranteed if developers are required to correct all building and fire code violations. Accordimgly, all units should be certified by the city before the developer is allowed to convey title. As an alternative, the developer should be required to establish escrow accounts sufficient to cover the costs of all improvements and corrections necessary after conveyance.

To protect purchasers and cncourage physical rehabilitation fur-

158. See note 149 supra.

159. In addition, some local jurisdictions may wish to follow the Los Angeles ordinance and provide for relocation expenses and rent difference ratios. See note 149 supra.

160. See notes $138-39$ supra and accompanying text.

161. See notes $146-48$ supra and accompanying text.

162. See notes 150-51 supra and accompanying text. 
ther, regulations should require developers to warrant the common areas and systems of the entire condominium complex for two years. The developer should also be required to warrant the mechanical equipment of the mdividual units for one year. ${ }^{163}$ The two-year warranty would begin when the first unit of the coniplex is sold, and the one-year warranty when the individual unit is conveyed.

3. Incentives to Increase Construction and Maintenance of Rental Housing. If reasonably priced rental units were available, condominium conversions would pose fewer problems. Further, if rental housing maintenance were made niore attractive, fewer conversions would occur. Rather than attempting to restrict conversions, thus leaving the existing housing problems to manifest themselves in other forms, legislatures should enact provisions encouraging growth in the rental sector. In addition, regulations should be considered that would facilitate unit purchases for those tenants who wish to purchase. A brief overview of some potential solutions follows.

(a) Facilitating tenant purchases. Many displaced low and noderate incoine tenants would purchase their units if they could afford to do so. Federal and local government subsidies should be developed to facilitate such purchases. ${ }^{164}$ This assistance would provide nrany of the benefits of home-ownership, particularly equity accuınulation, to people who could not otherwise enjoy them. It would also give lower income residents a vested interest in their housing accommodations and thus extend the useful life of many buildings that would otherwise deteriorate. In this regard, condominium conversions could be considered for some publicly assisted or publicly operated rental liousing. ${ }^{165}$

Government assistance could take the form of mortgage insurance, combined with interest-free or low-interest loans to low and nnoderate income purchasers. ${ }^{166}$ This would bring purchase prices within the means of many tenants who would otherwise be displaced. Sucli funding might come from the federal government, supplemented with local funds, made available as the improvements brought about by conversion increase local tax revenues. Alternatively, states might consider a conversion tax, sucli as that proposed by Montgoinery County Execu-

163. See notes 152-54 supra and accompanying text.

164. See, e.g., Housing and Urban Developinent Act of 1968, § 236, 12 U.S.C. \& 1715z (1976) (mortgage insurance and interest subsidy for low and moderate income home buyers); Housing Act of 1954, § 221(d)(2), 12 U.S.C. § 17151 (1976) (nortgage insurance for low and inoderate income families, especially those displaced by urban renewal); H. WoLMAN, supra note 79, at 11114.

165. See Chicago Tribune, supra note 64 , at 2 , col. 1.

166. See note 164 supra. 
tive Charles Gilchrist, to help finance assistance plans. ${ }^{167}$ Another option would be for states to finance partially the downpayments of qualified purchasers im the form of loans to be repaid either when the unit is sold or when the mortgage is retired.

(b) Improving the attractiveness of the rental housing sector for investors. One of the primary aims of any regulation should be to encourage growtl in the rental market by making the rental market more attractive for investment. The essential action that should be considered is decontrol of rents. ${ }^{168}$ If rents were allowed to return to their normal market level, maintenance of rental housimg would again become profitable. Profitability would, in turn, stimulate new investment, which would ease the current shortage of rental housing.

There are, lowever, political and practical realities that must be faced when considering rent decontrol. It is extremely difficult pohtically to advocate decontrol:

Rent controls represent one of those economic pohicies which, once implemented, is difficult to repeal. The beneficiaries are numerous and the benefits to them are substantial. With the passage of time, the expected shock of decontrol to household living expenses gets progressively worse, making it difficult for elected officials to favor decontrol publicly. ${ }^{169}$

In order to deal with the political realities of decontrol, rent subsidies could be employed to make rental housing affordable for the poor and the elderly. This shift of the subsidization burden from landlords to government should help attract investment to the rental housing sector. State legislatures should consider rent subsidy programs such as those currently undertaken by the federal government. ${ }^{170}$ Subsidization would avoid the political difficulties of decontrol as well as the undue hardship on lower income groups forced to pay an unrealistic portion of their mcomes for rent.

\section{CONCLUSION}

The current condominiuin conversion phenomenon is the result of many supply and demand factors at work in the housing market. Conversion can provide numerous advantages to society, but these advan-

167. See notes 128-34 supra and accompanying text.

168. See H. Wolman, supra note 79, at 109-11; Rydenfelt, The Rise and Fall of Swedish Rent Control, in Rent Control 176-81. See generally Utt 89.

169. Utt 90.

170. See, e.g., Housing and Community Development Act of 1974, § 8, 42 U.S.C. § $1437 \mathrm{f}$ (1976) (rent subsidies to lower incoine families to help them afford decent housing within the private market). See also H. Wolman, supra note 79, at 67-73; Walker, An Income Supplement Program, in RENT CONTROL 201-12. 
tages are acconipanied by significant disadvantages for displaced tenants, the poor, and the elderly. Thus, regulators face the difficult task of trying to encourage the conversion process while affording tenants the protection they deserve. Many of the current regulatory schemes severely restrict conversion in an attempt to protect tenants. Such regulations are shortsighted and will probably prove ineffective as a ineans of preserving the ever decreasing rental inarket.

The Uniform Condominium Code and the Model Condominiun Act provide solid foundations for inodel tenant protection schenies. State regulators should augnient this foundation by imposing conversion taxes and insuring that tenants have rights of first refusal. Further, regulators should reniove disincentives to investinent in the rental sector. Only this two-pronged approach of encouragnig housinig development while protecting tenants can provide a truly equitable, long tern solution to the housing crisis manifested by the condominiuni conversion phenomenon. 